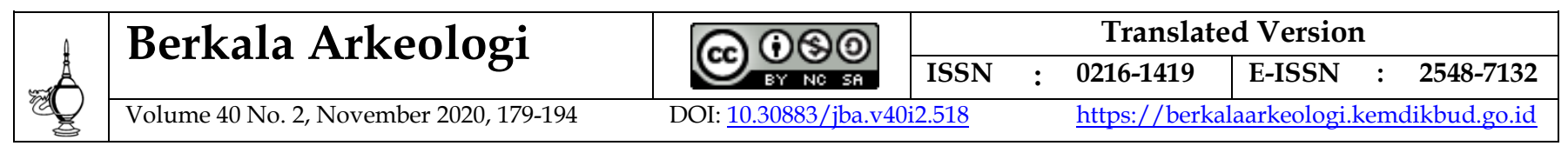

\title{
BATU CAVE: PREHISTORIC OCCUPATION OF MERATUS MOUNTAINS, SOUTH KALIMANTAN
}

\section{GUA BATU: HUNIAN PRASEJARAH DI PEGUNUNGAN MERATUS, KALIMANTAN SELATAN}

\author{
Nia Marniati Etie Fajari', Muhammad Wishnu Wibisono² \\ Regional Agency for Archaeological Research in South Kalimantan Province ${ }^{1}$, \\ Vajra Amarta Reksa² \\ nia.oktrivia@gmail.com
}

\begin{abstract}
ABSTRAK
Studi awal di perbukitan karst Pegunungan Meratus di Kabupaten Kotabaru menemukan ceruk dan gua yang diindikasi memiliki jejak hunian prasejarah. Salah satunya adalah Gua Batu yang berada di Desa Batangkulur, Kelumpang Barat. Artikel ini mendiksusikan hasil ekskavasi yang dilakukan di Gua Batu pada tahun 2018. Permasalahan yang diajukan adalah apa bukti hunian dan bagaimana kehidupan manusia pada masa lalu di Gua Batu. Data diperoleh dari ekskavasi yang membuka lubang uji pada dua lokasi yang berbeda. Temuan ekskavasi dianalisis secara kuantitatif dan kualitatif. Analisis kuantitatif dilakukan untuk mengetahui kuantitas dan persentase temuan. Analisis kualitatif meliputi klasifikasi awal, yang membagi data arkeologi sesuai dengan jenis, bentuk, dan gayanya. Hasil analisis menunjukkan bahwa Gua Batu merupakan gua hunian dengan aktivitas hidup yang mengandalkan pada sumber daya di sekitarnya. Eksploitasi sumber daya lingkungan terlihat pada pemanfaatan beberapa jenis fauna darat dan air sebagai salah satu sumber makanan yang utama. Berbagai jenis peralatan dibuat dengan memanfaatkan batuan, serta sisa makanan berupa pecahan tulang dan kerang.
\end{abstract}

Kata kunci: Gua Batu; prasejarah; Pegunungan Meratus; gua hunian

\section{ABSTRACT}

Preliminary studies in the karst hills of the Meratus Mountains in Kotabaru Regency found rock-shelters and caves that were indicated to have traces of prehistoric dwellings. One of them is Batu Cave which is in Batangkulur village, Kelumpang Barat district. This article discusses the results of excavations carried out in Batu Cave in 2018. The problems raised on proof of occupancy and how human life in the past in Batu Cave. Archaeological data were obtained from excavations by using test-pit at two different locations. The excavation findings were analyzed quantitatively and qualitatively. Quantitative analysis was carried out to find out the quantity of findings. The qualitative analysis includes an initial classification, which divides archeological data according to the type, form, and style. The results show that Batu Cave is cave dwelling with living activities that rely on the surrounding resources. Exploitation of environmental resources shown in the use of several types of terrestrial and aquatic fauna as one of the main food sources. Various types of tools were made using rocks, as well as bones and shells.

Keywords: Batu Cave, prehistory; Meratus Mountains; cave dwelling

Article Submitted : :06-01-2020

Article Accepted : : : : 


\section{INTRODUCTION}

Pegunungan Meratus (Meratus Mountains) are one of the geographical icons in South Kalimantan Province. These mountains stretch across 10 regencies, namely Banjar, Tanah Laut, Tanah Bumbu, Kotabaru, Balangan, Tabalong, Hulu Sungai Utara, Hulu Sungai Tengah, Hulu Sungai Selatan, and Tapin. The karst hill partially ranges along the mountainous region. In the southeast, the Meratus karst hills are in Kotabaru Regency. The research that was first carried out in 2018, successfully found several caves containing archaeological findings, namely Batu Cave, Gua Hasan Basri, Ceruk Rasidi, Ceruk Gunung Bambu Else, Ceruk Gunung Beringin, Gua Takasima 2, Ceruk Bali, and Gua Isur (Fajari et al. 2018). The archaeological findings obtained indicated that there were residential activities in Batu Cave, Ceruk Rasidi 1, and Ceruk Bali. All three have the physical requirements needed as a place to live. Caves used as dwelling caves generally have morphological feasibility, air circulation, sunlight intensity, and the presence of archaeological findings (Nurani and Hascaryo, 2010).

The results of the survey show that Batu Cave site has the most complete surface findings (Table 1). This prompted excavation activities in Batu Cave. Batu Cave site lays in Batang Kulur Village, Kelumpang Barat District, Kotabaru Regency, South Kalimantan. Geographically, Batu Cave is located at $2{ }^{\circ} 28139.4$ "South Latitude and $116^{\circ} 4$ '30.674" East Longitude. Batu Cave is a rock shelter with an elongated shape, which is east-west oriented. Air circulation and light intensity are very good in all parts of the rock shelter. On the flat and dry surface were found stone artifacts, pottery fragments, shell artifacts, shells and bones, as well as human tooth fragments (premolars). Batu Cave is located in Bukit Batu, which is a single karst hill in a conical shape (like an inverted bowl). Bukit Batu is composed of two similar hills which are closely located resembling a stone furnace. The community around the location calls it Bukit Tanggar Tungku (Fajari et al., 2018). Based on surface finds, Batu Cave is indicated as a residential cave in the prehistoric time.

Table 1. Cave sites in the Kelumpang Barat District

\begin{tabular}{|c|c|c|c|c|c|c|}
\hline Cave Sites & $\begin{array}{l}\text { Stone } \\
\text { Artifacts }\end{array}$ & Pottery & $\begin{array}{l}\text { Shellfish } \\
\text { Artifacts }\end{array}$ & Dental & Bone & Shells \\
\hline Batu Cave & 16 & 4 & 4 & 5 & 70 & 165 \\
\hline Hasan Basri Cave & 3 & - & - & - & 27 & 4 \\
\hline Gunung Else Cave & 1 & - & - & - & - & 13 \\
\hline $\begin{array}{l}\text { Gunung Bambu Else } \\
\text { Rockshelter }\end{array}$ & 5 & 10 & - & - & - & 7 \\
\hline Rasidi 1 Cave & 38 & 1 & - & - & 2 & 12 \\
\hline $\begin{array}{l}\text { Gunung Beringin } \\
\text { Rockshelter }\end{array}$ & 17 & 5 & - & - & 7 & 10 \\
\hline Gunung Liang Udud Cave & - & 17 & - & - & - & 80 \\
\hline Takasima 2 Cave & 25 & - & - & - & - & 2 \\
\hline Bali Rockshelter & 7 & - & - & - & - & - \\
\hline Isur Cave & 2 & - & - & - & 18 & 15 \\
\hline $\begin{array}{l}\text { Kebun Sawit (Palm Oil } \\
\text { Plantation) }\end{array}$ & 30 & 2 & - & - & - & 8 \\
\hline
\end{tabular}

Source: analysis of research results in 2018

This research aims to reveal more details about human life used to live on this site. Besides that, this research also tries to present evidence of life and to reconstruct the life that happened in Batu Cave. 
Archaeological research in Kotabaru Regency has succeeded in finding indications of human activity in several caves in the Kotabaru karst hills. This research began with a cave survey in three districts, namely Kelumpang Barat, Kelumpang Hulu, and Hampang. The three districts are close to Mantewe in Tanah Bumbu Regency, which had formerly been researched (Figure 1).

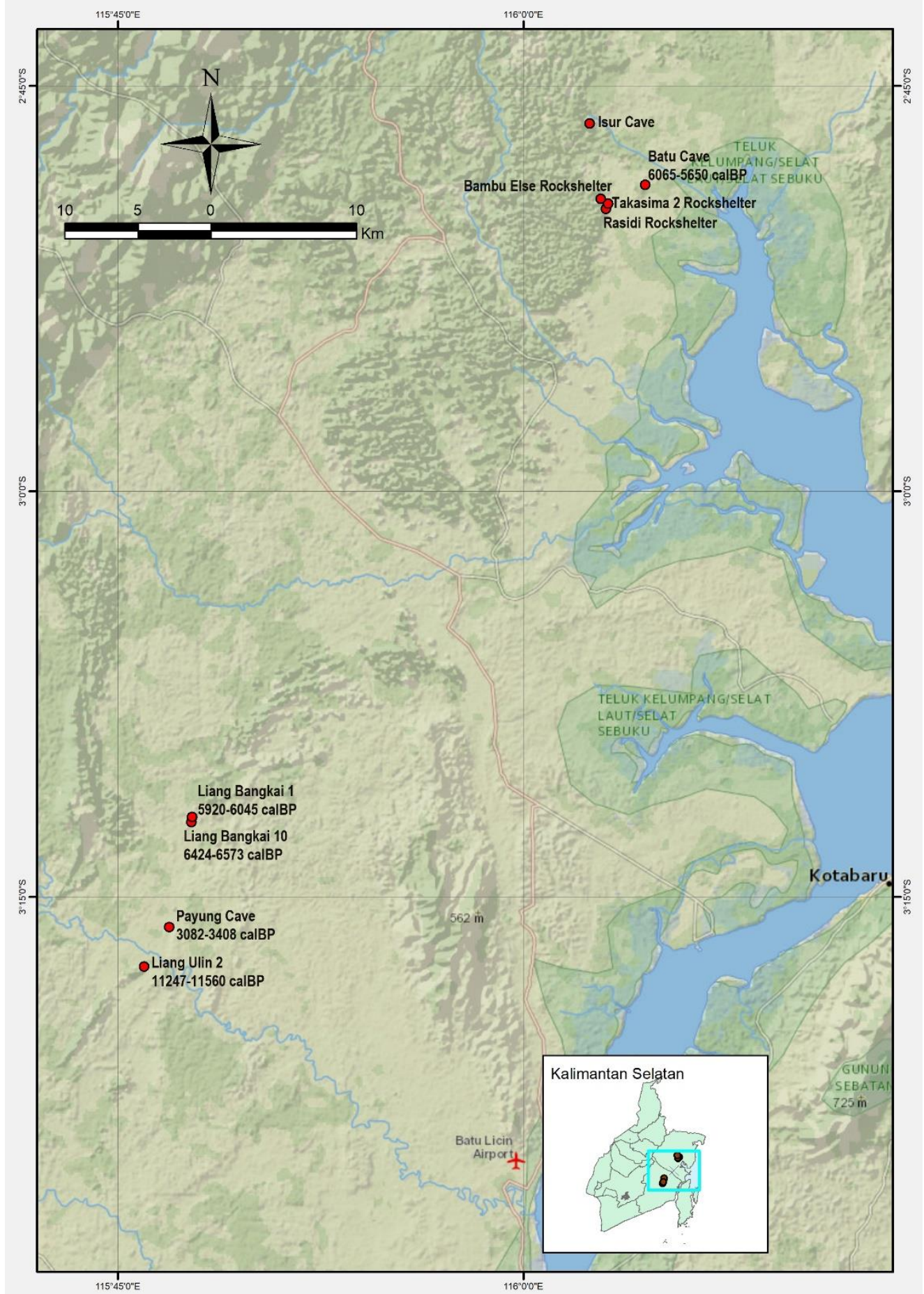

Figure 1. The Location of Batu Cave and Other Settlement-Cave Sites in the Southeastern Meratus Mountains

(Source: Regional Agency for Archaeological Research in South Kalimantan Province, 2018 drawn by Ulce Oktrivia) 
Intensified archaeological research in Mantewe district managed to find some occupancy sites, namely Liang Bangkai 1, Liang Bangkai 10, Ceruk Bangkai 3, Gua Sugung, Gua Landung, Gua Harimau, Gua Pembicaraan, Liang Ulin 2, and Gua Payung (Fajari and Kusmartono, 2013; Fajari and Oktrivia, 2015; Oktrivia et al, 2013; Sugiyanto, 2015). In general, cave dwellings in Mantewe display the use of human subsistence depending on terrestrial ecosystems and aquatic resources. Evidence of Liang Bangkai 1 occupancy is shown by findings in the form of stone artifacts, bone tools, pottery fragments, animal bone fragments, and shells (Sugiyanto et al., 2015). Liang Bangkai 1 was a residential site indicated as a location for the creation of stone artifacts. This is based on the abundant amount of rock artifact data in the excavation of Liang Bangkai 1 (Sugiyanto et al, 2014).

Apart from Liang Bangkai 1, traces of activity were also found at Liang Ulin 2, which has three terraces. On the upper terrace of Liang Ulin 2, archaeological data were found, in the form of stone artifacts, pottery and bone tools, as well as fragments of animal bones, shells, skeletons and human teeth. Burning activities had been carried out to process food, indicated by several findings of burnt bones (Oktrivia et al, 2013). Several types of tools made to meet daily needs include earthenware, stone artifacts, and bone tools. Making tools was one of the human efforts to exploit natural resources to survive (Fajari and Oktrivia, 2015). Not far from Liang Ulin 2, the dwelling site is also located at Gua Payung. The findings of stone artifacts and bone jewelry, as well as shells and bone fragments are evidence of occupancy in Gua Payung. The occupancy in Gua Payung is known to have a neolithic cultural style at a chronology of 3007-3013 calBP (Fajari and Kusmartono, 2013).

Evidence of occupancy was also found in the northern Meratus Mountains. Intensive research in Bukit Batubuli, Muara Uya District in Tabalong Regency found Gua Babi, Gua Tengkorak, and Gua Cupu. The human culture in Batubuli had a pre neolithic cultural character at $5050 \pm 100 \mathrm{BP}$ or around 5688-5898 calBP (Widianto and Handini, 2003).

\section{METHODS}

This research is a descriptive study which was carried out in several stages, namely data collection, analysis, and interpretation to answer the problems raised. Data collection was performed by surveying the cave to determine its archaeological potential, continued with excavations in Batu Cave which has an indication as a dwelling cave. Excavation was carried out by opening two $2 \times 2 \mathrm{~m}$ sized TP. The technique applied is a lot system, a technique that combines spits and layers. The technique uses the spit interval as an arbitrary guide to the depth, while taking into account changes in soil layers in the excavation box.

The excavation findings were analyzed quantitatively and qualitatively. Quantitative analysis aims to calculate the quantity and percentage of findings. The qualitative analysis involves the classification, formal analysis, and contextanalysis. Classification aims to construct the boundaries of the observed group (Clarkson and O'Connor, 2006). Eco-facts were grouped based on their types, namely bones, teeth, shells and charcoal. Artifacts were classified based on their material, namely stone artifacts, bone artifacts, shell artifacts, and pottery. The formal analysis of stone artifacts is based on the scheme prepared by Andrefsky, who divides stone artifacts into two groups, namely tools and non-tools 
(Andrefsky, 1998). Observations of bone artifacts and shell artifacts were based on the traces of work that had been found. Bone artifacts found in the form of spatula and spatulate. The shell artifacts are generally crescent like-shaped and have traces of workmanship on their edges. Pottery fragment analysis was carried out by grouping them based on the edges, the body and the bottom. Further observations of pottery were carried out to determine the technology and decorative motifs applied.

Meanwhile, context-analysis that emphasizes the relationship among the archaeological data was carried out by observing the matrix, location, and spatial and temporal distribution (Tim Penulis, 1999). The results of the analysis then become the basis for the interpretation of the data, leading to the overview of the prehistoric settlements in Batu Cave.

\section{RESEARCH RESULTS}

An archaeological survey found the quantity and variety of surface finds indicating human occupational activities in Batu Cave. Batu Cave has suitable physical conditions for residential location, namely flat and dry floors, as well as good light intensity and humidity. The excavation was carried out to prove this assumption. Two test pits measuring $2 \times 2 \mathrm{~m}$ were dug at different locations. The two test pits were referred to as TP 1 and TP 2 . TP 1 is located in the western part of the cave, which is on the highest floor surface, while TP 2 is in the eastern part on a gentler floor surface (Figure 2). The excavation of TP1 aims to find evidence of human activity in Batu Cave and its vertical distribution in the soil layer. TP2 excavation aims to determine the horizontal distribution of archaeological data, as well as the transformation process that occurs in Batu Cave.

The excavation of TP 1 was carried out to a depth of $60 \mathrm{~cm}$ from the ground. TP 1 stratigraphy consists of three layers, namely A, B, and C (Figure 3). Layer A is a gray, fine clay soil. In this layer found features of ash as well as a number of bone fragments and burned shells. Layer B is reddish brown sandy clay at a depth of $25-45 \mathrm{~cm}$. Layer $C$ is red sandy clay with a depth of 30 to $60 \mathrm{~cm}$. The end of layer, $\mathrm{C}$ is filled with bedrock which is part of the floor of the cave. The excavation of TP 1 found a variety of archaeological data with a total of 17,938 pieces. The distribution of finds was mostly found in layer $\mathrm{C}$ with a total of $52 \%$, while the finds from layer A amounted to $11 \%$ and layer B amounted to $37 \%$. The results of the excavation of TP 1 can be seen in Table 2 .

The excavation of TP 2 reveals two soil layers, namely A and B (Figure 4). TP 2 does not have a layer of soil mixed with ash like in TP 1 . The soil in layer A of TP 2 is brown with loose sand and moist texture. The soil layer is dense with irregular-shard-formed shells and bones. Layer B has sandy clay textures and reddish color. The soil in layer $B$ contains both large and small boulders of limestone. The distribution of the findings was mostly found in layer B with a total of $58.1 \%(n=10,991)$, while the findings from layer A were $41.9 \%$ (Table 3$)$. 


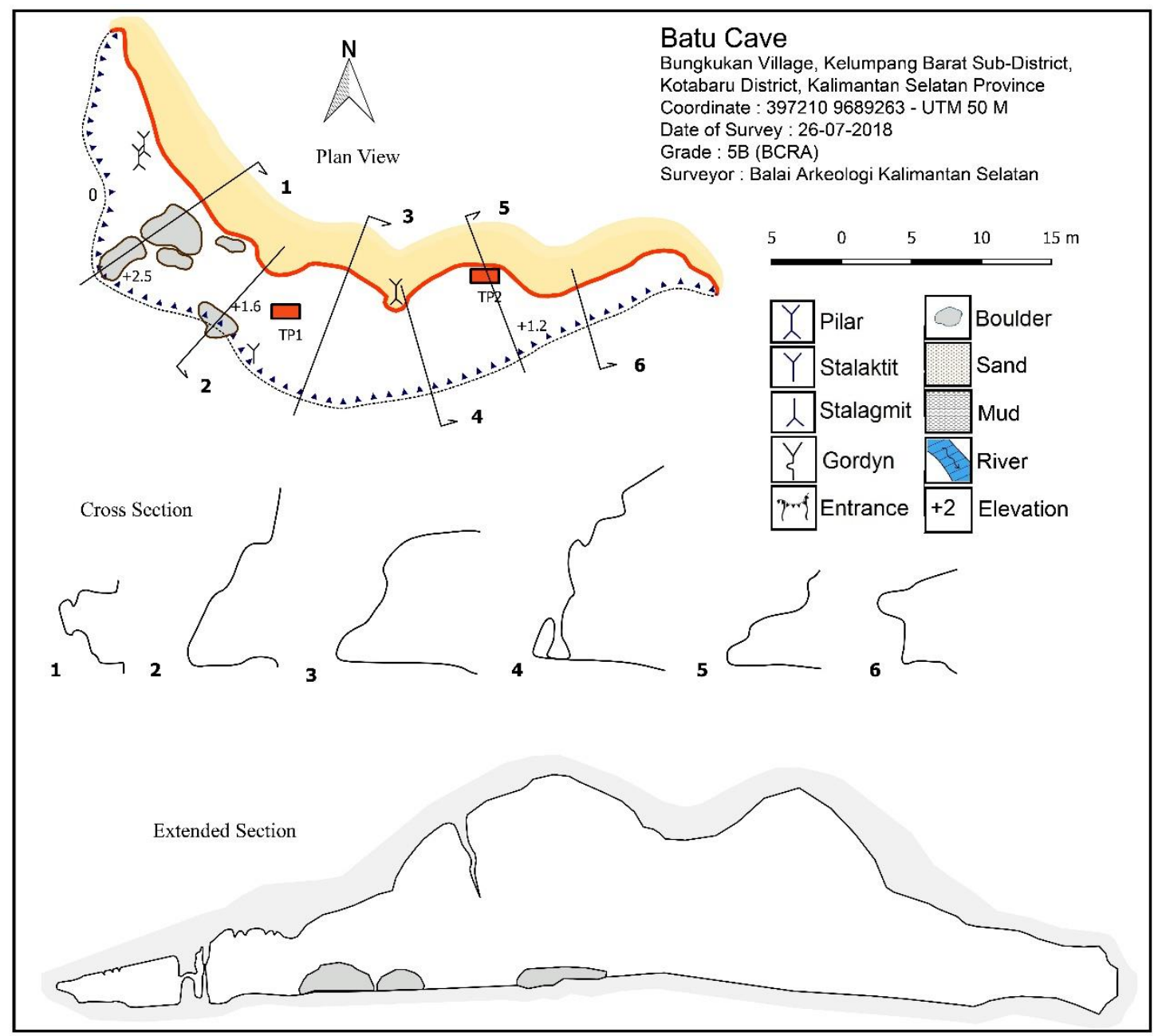

Figure 2. The Site Plan of the Batu Cave and the Position of the Excavation TP 1-TP 2 (Source: Regional Agency for Archaeological Research in South Kalimantan Province, 2018, drawn by Thomas Suryono)

Table 2. Archaeological Data from TP 1

\begin{tabular}{llllllll}
\hline Layer & Lithic & Pottery & $\begin{array}{l}\text { Bones } \\
\text { Artifact }\end{array}$ & $\begin{array}{l}\text { Shell } \\
\text { Artifact }\end{array}$ & Bones & Dental & Shell \\
\hline A & 41 & 9 & 1 & 76 & 132 & 2 & 1792 \\
B & 663 & 24 & 18 & 260 & 1021 & 21 & 4609 \\
C & 738 & 5 & 17 & 115 & 434 & 8 & 7952 \\
\hline
\end{tabular}




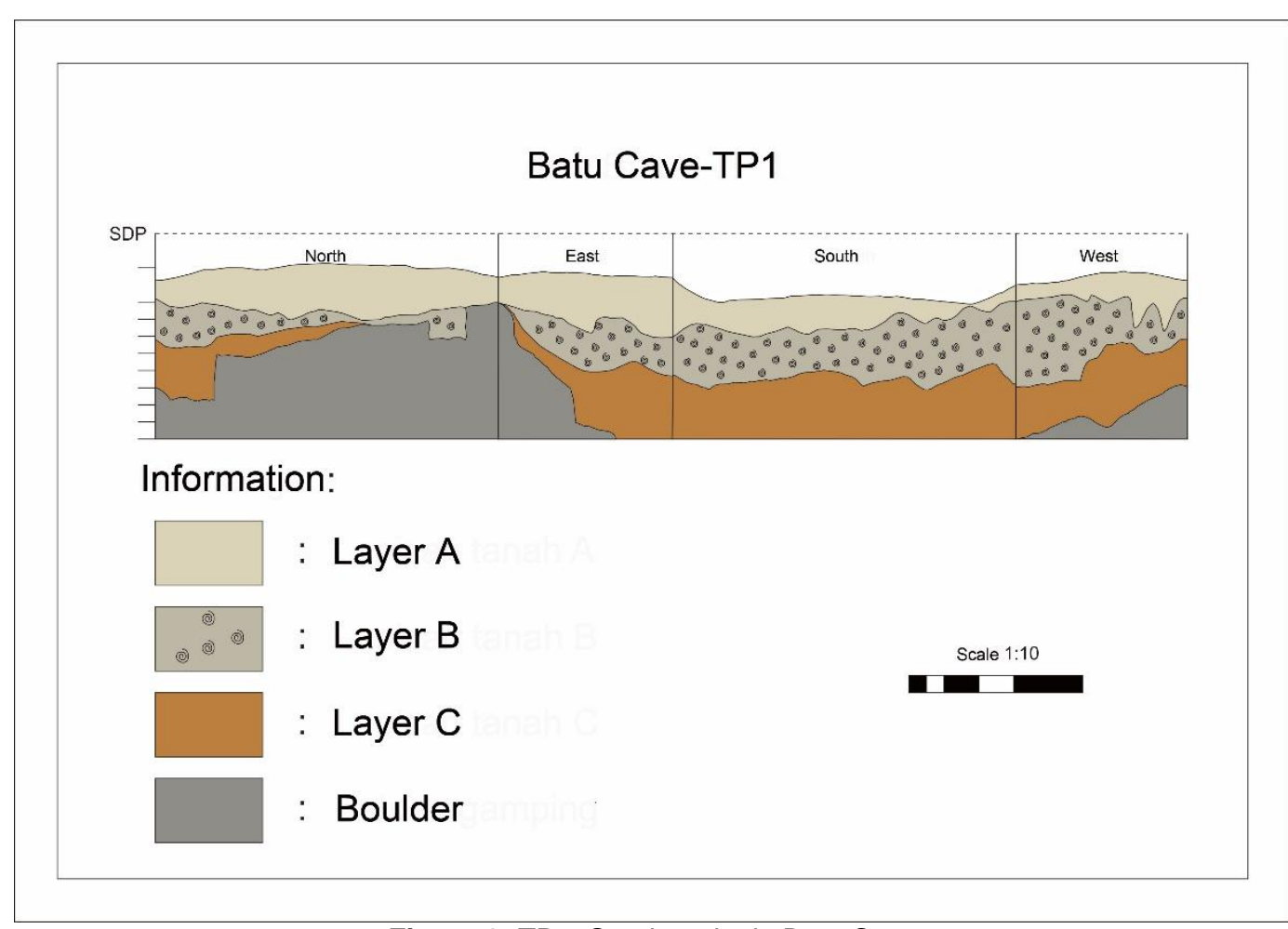

Figure 3. TP 1 Stratigraphy in Batu Cave

(Source: Regional Agency for Archaeological Research in South Kalimantan Province, 2018, drawn by M. Wishnu Wibisono)

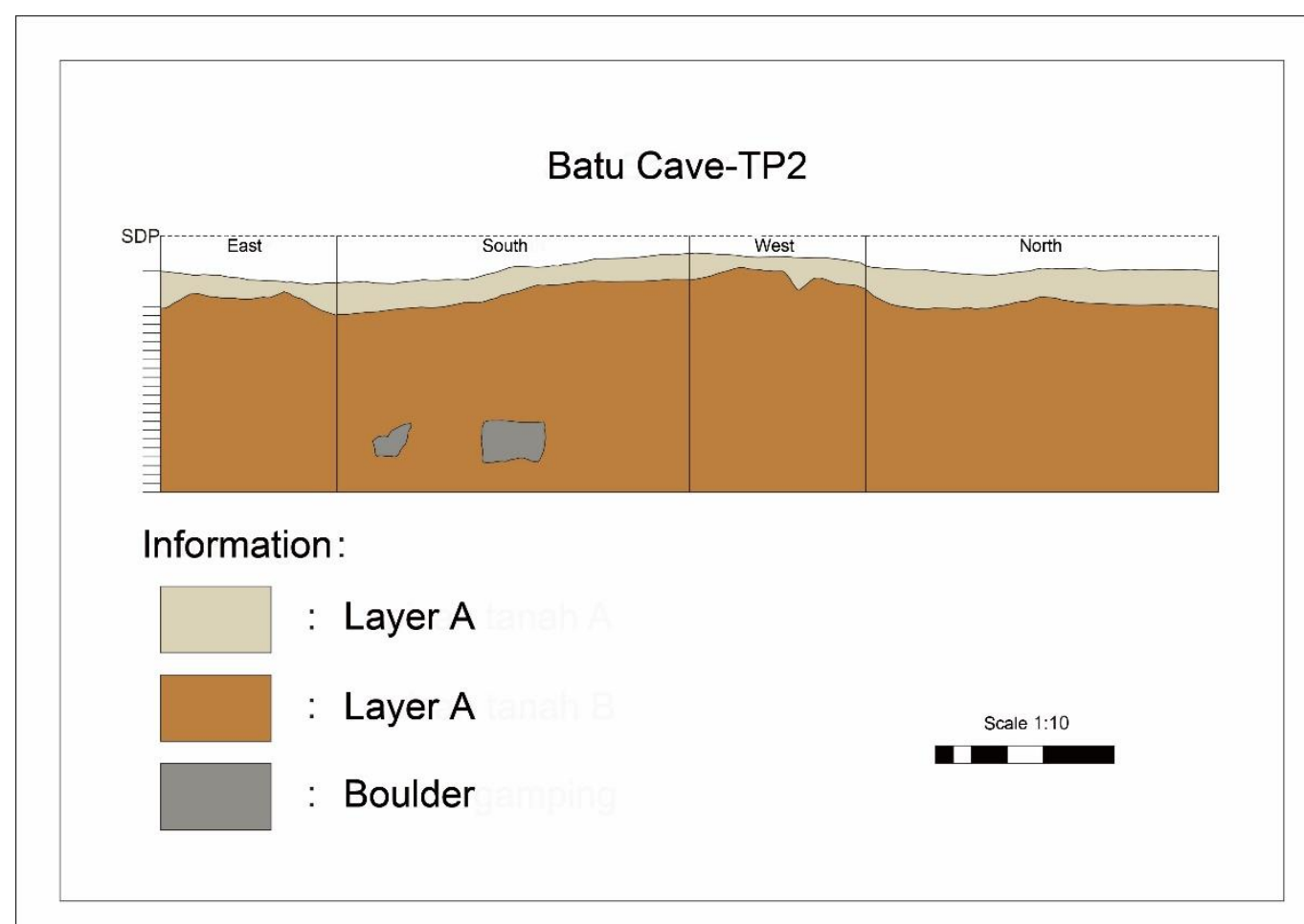

Figure 4 . TP 2 Stratigraphy in Batu Cave

(Source: Regional Agency for Archaeological Research in South Kalimantan Province, 2018, drawn by M. Wishnu Wibisono) 
In general, the finds of the excavation of the Batu Cave are divided into two groups, artifactual and eco-factual. The types of artifacts found were stone artifacts, pottery, bone artifacts, and shell artifacts. There are two types of stone artifacts, namely tools and non-tools. The grouping was based on the scheme compiled by William Andrefsky (Andrefsky, 1998). Types of stone tools include bifacial or monofacial tools, shale tools, and core stones. Meanwhile, the group of non-tool consists of splinters and chips(debitage)(Andrefsky,1998).

Table 3. Archaeological Data from TP 2

\begin{tabular}{llllllll}
\hline Layer & Lithic & Pottery & $\begin{array}{l}\text { Bones } \\
\text { Artifact }\end{array}$ & $\begin{array}{l}\text { Shell } \\
\text { Artifact }\end{array}$ & Bones & Dental & Shell \\
\hline A & 392 & 26 & 25 & 291 & 483 & 24 & 3366 \\
B & 1096 & 23 & 142 & 104 & 2049 & 41 & 2929 \\
\hline \multicolumn{7}{c}{ Source: the analysis of research in 2018. }
\end{tabular}

Stone tools from Batu Cave accounted for $10.1 \%$ of the total stone artifacts found. The stone tools consist of core tools and shale tools. Core tools are the remaining rock material with fields formed due to pruning in stone tool production (Poesponegoro and Notosusanto, 2010). Core tools were the most common type of stone tools ( $63.4 \%$ of the total stone tools). The analysis shows that core stones have two types, namely unidirectional core tools and multidirectional core tools. Unidirectional core tools have a one-way pruning in a plane of hit plain. This type is the dominant core-stone type in Batu Cave. One of the core tools found has the characteristics of hoabinhian technology, which is a thorough flaking on one side creating sharp edges all over the edges (Wiradnyana, 2017) (Figure 5). Meanwhile, multidirectional core tools are the result of flaking done towards two or more flaking planes.

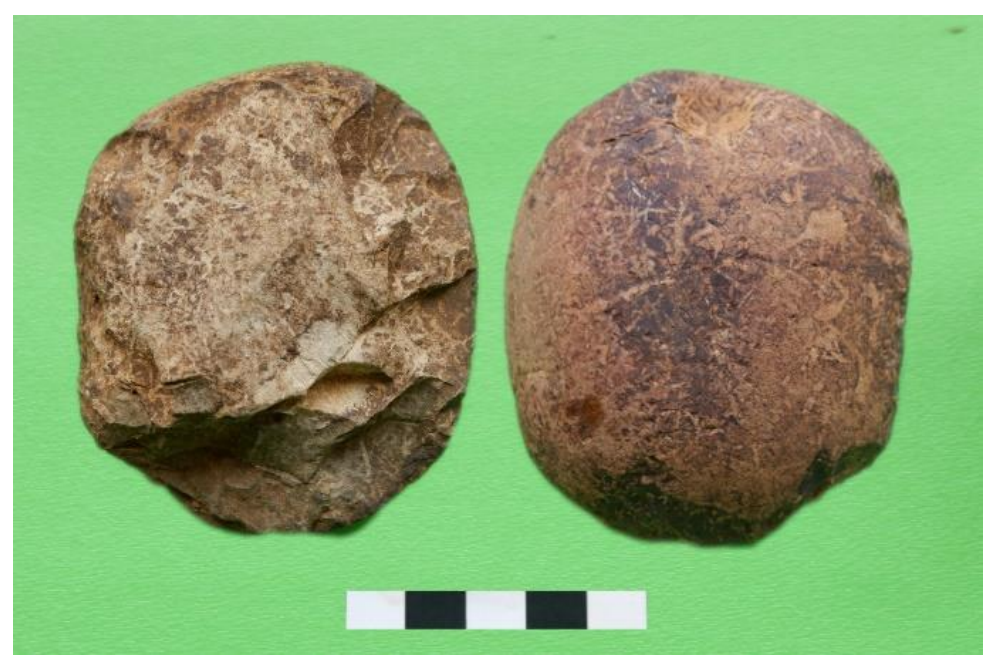

Figure 5. Stone Tools Core Which Are Characterized by Hoabinhian Technology (Source: Regional Agency for Archaeological Research in South Kalimantan Province, 2018) 


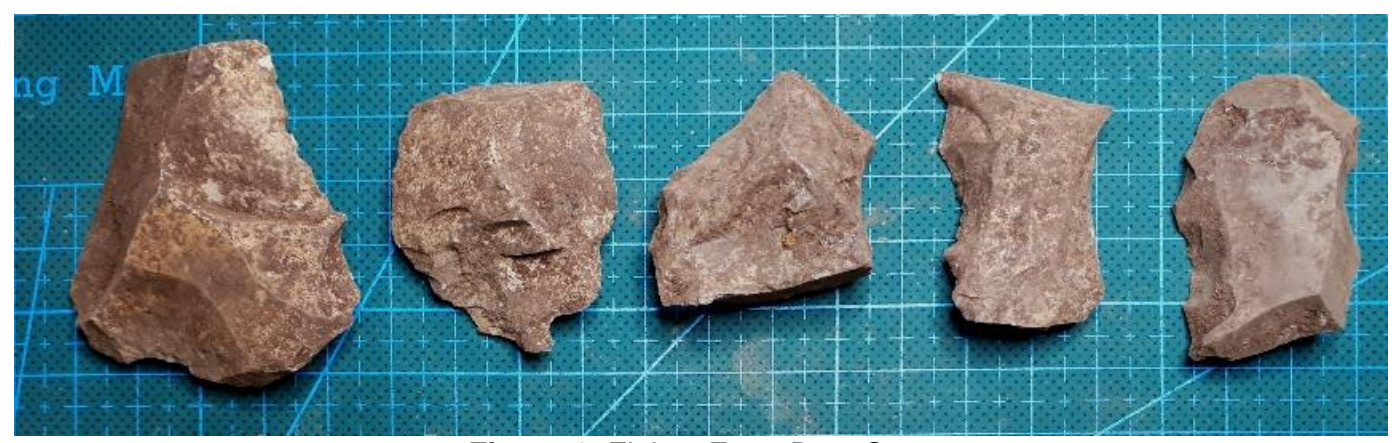

Figure 6. Flakes From Batu Cave

(Source. Regional Agency for Archaeological Research in South Kalimantan Province, 2018)

The non-tools stone artifacts were the most common type, which was $89.9 \%$ of the total. Andrefsky divides it into two, namely flakes and piece esquille (Andrefsky, 1998). This type of shale is referred to as a proximal shale, which is a non-tool stone artifact that has a complete shale morphology without any cracks or other signs of work (Andrefsky, 1998). Proximal shale is the most common type of stone artifact found and is quite easy to recognize compared to other types. Apart from the tools and non-tools group, it was also found that hammer stones and crusts were trimmed. The stone was found to have an oval shape with a scar on one side. These wounds are the scars that arise as a result of colliding with other stones, when used to break and shape stone tools. Only one piece of crust trimmed from Batu Cave was found, tended to have irregular and very simple forms.

The pottery from Batu Cave have shards at the edge and the body of the container. The concave traces on its surface and some irregular striation lines indicate that the pottery was made using the ground-to-ground technique and slow wheel (Sharer and Ashmore, 2003; Tim Writer, 1999). Most of the pottery fragments are plain without decorative motifs, and only a few of them have decorative motifs. The types of decorative motifs found are trellis and irregular geometric lines.

Batu Cave artifacts were made of long bones, simply modified, namely by dividing the middle to produce a concave cross section. Further works were performed at the edges creating sharper form. The types of bone artifacts found were spatulate and spatula. Both have different morphology. The spatulate is characterized by a sharp tip resulting from trimming or rubbing (Prasetyo, 2004). Trimming done on both sides intensively resulted in symmetrical pointed ends, while trimming on one side only produces asymmetrical tapering (Prasetyo, 2004). The spatulate found in Batu Cave has an asymmetrical tip. Meanwhile, the spatula has a characteristic in the form of a flat and wide sharpener, which is formed by rubbing the inside or outside of the bone to produce a sloping tip (Prasetyo, 2004). The spatula from Batu Cave is generally not scrubbed intensively. This is indicated by the concave and uneven center of the bony apparatus. 


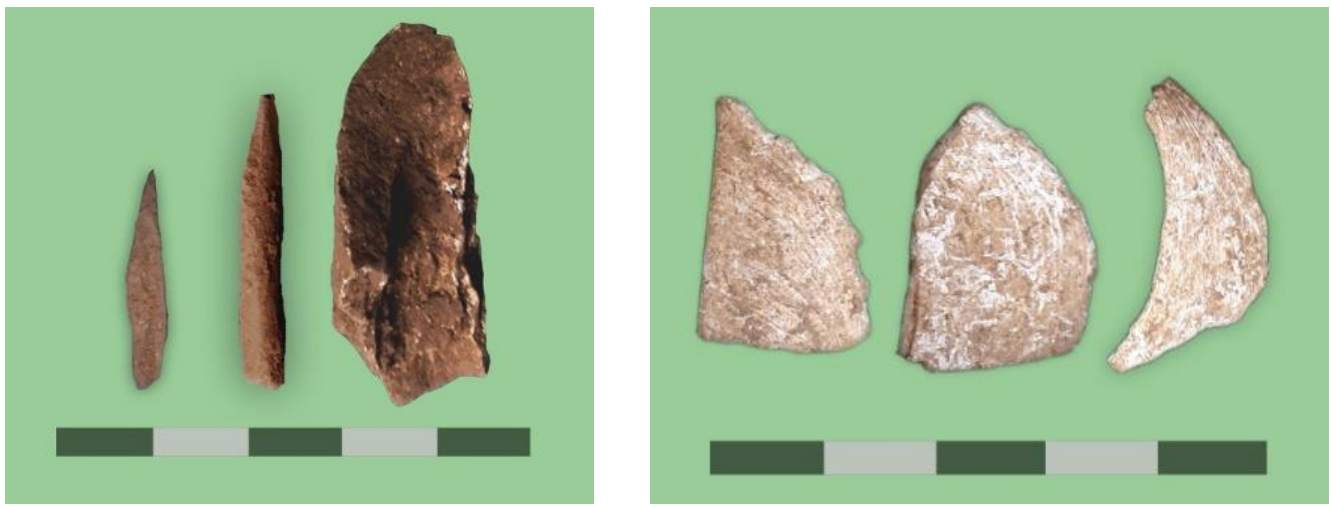

Figure 8. Bone and Shells Artifacts From Batu Cave

(Source: Regional Agency for Archaeological Research in South Kalimantan Province, 2018)

Shell artifacts in Batu Cave were made from bivalve shells, either in whole or in pieces. The shell tool was made in simple form, without any complicated modifications. Work was done by slightly eroding the posteriorly without changing the complete shape at all. The abrasion marks can sometimes be seen by unaided eyes, but there are some clam tools with barely visible scrapings. The percentage of shellfish tools in Batu Cave indicates that shellfish are one of the most widely used alternative ingredients (food scraps), compared to bones.

Shellfish was the most common ecofacts with a percentage of $83 \%$ ( $\mathrm{n}=$ $24,863)$. Other types of ecofacts include bone fragments, teeth and charcoal. Most of the shells and bone fragments are small fragments that cannot be identified.

The shells from the excavation of Batu Cave were grouped into three types, namely Gastropods, Bivalves, and unidentifiable shellfish. Gastropods are the most common type, namely $40 \%(\mathrm{n}=20,242)$. Some of the identified families are Thiaridae, Viviparidae, Neritidae, Pleuroceridae, Amnicolidae, Conidae, Trochidae, Planorbidae, and Cypraeidae. The most dominant types include Thiaridae and Viviparidae. The Thiaridae and Viviparidae or what are referred to as 'ketuyung' in local languages are one of the sources of animal protein consumed by humans. Most Thiaridae shells have the apex cut off, which indicates cutting to remove the clam flesh.

Bivalves are the second largest phylum after Gastropods, which are characterized by a pair of shells with hinges that can be closed and opened (Reitz and Wing, 2008). There are not as many types of bivalves as gastropods. The findings of bivalves that can be identified include the families Corbiculidae and Veneridae. Types of Corbiculidae are shellfish that live in brackish water mangrove habitats, while Veneridae are seashells that live in saltwater. Freshwater and saltwater shells were one of the main sources of human consumption at that time.

Apart from shellfish, foods were obtained from animals. Bone fragments are the second largest species of ecofacts after shellfish. The bone fragments are classified based on their form and type, namely long bones, chondylated bones, vertebrae, and bone fragments that cannot be identified. Initial analyzes have identified the turtle plastron, remains of fish spines, fragments of crab claws, bear hooves and pig spines. The spinal structure has a distinctive shape, with the neural canal and neural arch having a butterfly-like shape. The bone fragments collection in Batu Cave is assumed to be human food remains.

The teeth found from Batu Cave consisted of human and animal teeth. Human tooth fragments were found in the form of molars. The teeth found 
generally have a worn occlusal condition. The cuspid occlusal and dentin morphology is difficult to analyze. Some teeth are known to have traces of attrition, the damage to the hard tissues of the teeth due to the friction between the teeth. Dental attrition generally occurs in the elderly, namely as a result of the physiological process of chewing that lasts for a long time and the habit of chewing pinang palm (Noviyanti, 2014). However, the condition of the molar teeth from Batu Cave did not show any traces of chewing. As for animal teeth, they have not been identified so far.

\section{DISCUSSIONS}

The excavation results show that Batu Cave were used by humans as a place to live. Evidence of dwelling activity was obtained from several tools produced from stones, shells, bone fragments, and pottery. In terms of quantity, stone artifacts are the most common type compared to other artifacts. This shows that the inhabitants of Batu Cave tended to use and utilize rocks to make living tools. They also used food scraps in the form of clam shells and bone fragments to make tools. The use of clam shells as a material for making tools is an interesting option. Some literature on Asia-Pacific archeology states that the use of shells for toolmaking materials was only done when the source of rock material was insufficient. The shells had only been used as a 'substitute' material; tools produced from stones and shells have the same function (Szabo, Brumm, and Belwood, 2007). This didn't happen at Batu Cave. Shells and stones were both used as materials for making tools. The resulting shell tools also had a different shape from the stone tools.

The number of pottery fragments found indicates that the use of pottery for containers or daily needs was not intensive. If you compare the quantity of finds, the use of pottery in Batu Cave is not as intensive as in other sites, such as Payung Cave and Liang Ulin 2. The quantity of pottery found at the two sites is quite large. In addition to quantity, the pottery from Batu Cave has simpler decorative motifs than those from Payung Cave. Umbrella Cave pottery has various decorative motifs, including a round hole motif made with a puncture technique and the addition of a red slip to the outer surface of the pottery (Fajari, 2010). Similar to Payung Cave, the pottery from Liang Ulin 2 also has a red slip and a round hole motif (Oktrivia et al, 2013). Even though they have different decorative techniques and motifs, the technology used in the manufacture of pottery between Batu Cave, Payung Caves, and Liang Ulin 2 is similar, namely using face-to-ground technology and rotating wheels.

Ecofacts found in Batu Cave provide an overview of exploration of natural resources for food fulfillment. The main food source is obtained from the aquatic environment, both freshwater and brackish water habitats. The types used were Polymesoda erosa and Polymesoda expansa ${ }^{1}$. Meanwhile, land fauna consumed by humans included Suidae or pigs. The pig bone fragments found were in the form of an upper jaw and several parts of the spine.

Radiocarbon dating analysis was carried out with shell samples of Polymesoda erosa and Polymesoda expansa from TP 1 and TP 2. The analysis was

\footnotetext{
${ }^{1}$ The identification was carried out by Delta Bayu Murti, MA, from the The Museum and Center of Ethnographic Research, Universitas Airlangga
} 
carried out in the radiocarbon dating laboratory at the University of Waikato, results is displayed in Table 3. There raised an issue related to the results of the radiocarbon dating analysis ${ }^{14} \mathrm{C}$ done. The chronology obtained from the TP 2 shellfish sample seems to be reversed that the layer A has an older number than layers B and C. This is because the Polymesoda erosa shells sampled were transformed by the marine and land environment during their life. Clams live in brackish water habitats in mangrove forests, which are always affected by tides.

Table 3. Absolute Dating Analysis of Batu Cave

\begin{tabular}{llllllll}
\hline WK & $\begin{array}{l}\text { Site/TP/Spit/ } \\
\text { Layer/number }\end{array}$ & $\begin{array}{l}\text { Depth } \\
\text { (cm) }\end{array}$ & Material & $\mathbf{D}^{13} \mathbf{C}$ & $\mathbf{F}^{14} \mathbf{C} \%$ & $\begin{array}{l}\text { Results } \\
\text { (BP) }\end{array}$ & $\begin{array}{l}\text { Calibration } \\
\text { (calBP) }\end{array}$ \\
\hline 48647 & GBT/TP1/4/A/281 & -35 & Polymesoda & $-14.0 \pm 0.4$ & $50.6 \pm 0.2$ & $5471 \pm 30$ & $6065-5650$ \\
48645 & GBT/TP2/3/A/193 & -30 & Polymesoda & $-14.1 \pm 0.4$ & $52.7 \pm 0.2$ & $5148 \pm 34$ & $5683-5311$ \\
48644 & GBT/TP2/9/B/101 & -60 & Polymesoda & $-13.6 \pm 0.4$ & $54.0 \pm 0.2$ & $4954 \pm 33$ & $5520-5040$ \\
48646 & GBT/TP2/21/C/252 & -120 & Polymesoda & $-14.4 \pm 0.4$ & $54.8 \pm 0.2$ & $4828 \pm 28$ & $5316-4868$ \\
\hline
\end{tabular}

Source: The analysis results from The Waikato Radiocarbon Dating Laboratory at Waikato University, the calibration is based on (Ramsey, 2017; Reimer et al., 2013)

The results of research by Fiona Petchey et al. Thespecies Polymesoda erosa from the archaeological site in Caution Bay, PNG show that the extreme environmental conditions with high salinity and temperature can affect the isotope level on shellfish that live in these habitats (Petchey et al., 2013). Analysis using Polymesoda as a sample can give results several hundred years older or younger. The resulting chronology can also be an indication of changes in the environment at a certain time. For example, there was a decrease in sea level between layers A and $\mathrm{B}$, it can affect carbon conditions in the environment where Polymesoda is located (Petchey, personal communication via email 29 February 2019). The dating analysis using a sample other than Polymesoda is necessary in order to confirm the chronology of the occupancy in Batu Cave.

The chronology of the dwelling cave sites in the southeastern Meratus Mountains is obtained from Liang Bangkai 1, Liang Bangkai 10, and Gua Payung. Liang Bangkai 1 dated ranging from 3810-3867 BP and 14568-15514 BP (Sugiyanto and Jatmiko, 2014). Meanwhile, Liang Bangkai 10 has a chronology that ranges from 10286-10506 cal BP and 6424-6573 calBP (Sugiyanto and Jatmiko, 2014). Liang Bangkai 1 and Liang Bangkai 10 have the characteristics of a preneolithic-neolithic culture. The younger dates were obtained from the Gua Payung site, namely 3070 \pm 130 BP (3082-3408 calBP) and $2970 \pm 130$ BP (2973-3308 calBP). Gua Payung occupancy has the characteristics of a neolithic culture with findings dominated by pottery fragments (Fajari and Kusmartono, 2013).

The results obtained in Batu Cave adds new data for cave occupancy in the southeast Meratus karst. Evidence of occupancy from Batu Cave has several similar characteristics with other sites. The similarity can be seen in the variety of equipment produced and the choice of food sources available. Residential cave sites found in the Meratus Mountains include Liang Bangkai 1, Liang Bangkai 10 Ceruk Bangkai 3, Gua Sugung, Gua Landung, Gua Harimau, Gua Pembicaraan, Liang Ulin 2, and Gua Payung (F Fajar and Kusmartono, 2013; and Oktrivia, 2015; Oktrivia et al, 2013; Sugiyanto, 2015). Liang Bangkai 1 is known as a residential site with abundant stone artifacts findings (Sugiyanto et al., 2014). Liang Bangkai 1 and Batu Cave have something in common, namely artifactual data which is dominated by stone artifacts. However, the types of stone artifacts found at Batu Cave are not as complex as those from Liang Bangkai 1. 
The difference is in the form of the use of shells for tools, which so far has not been found in other dwelling caves. The geographic location of the rock caves close to the coast provides a usable source of materials. As discussed earlier, Batu Cave shell artifacts are made from the shells of brackish water Bivalves. Findings of brackish or saltwater shells are not widely found at cave sites that are some distance from the coastline, such as in Mantewe and Hampang. The limestone hills in Hampang are currently $22.5 \mathrm{~km}$ from the nearest coastline (Fajari et al., 2018). Similar to Hampang, there are not as many brackish/saltwater shells found in the Mantewe karst hills as in Batu Cave.

The type of saltwater shells found is the Cypraidae or known as kauri. Two Cypraids were found in Batu Cave in TP 2. This type of shell was also found in Liang Bangkai 1. The presence of Cypraidae at one cave site can be used as an indication of a relationship with occupancy in other areas. Suroto's research results state that in the 1900s, people living in the high mountains of Papua still used this type of shellfish as a medium of exchange. Some community groups, such as Kapauku and Mee who live around Lake Wissel, use the type Cypraea moneta shellfish as a medium of exchange, called kapaukumege (Suroto, 2009). This type of shell is also often used as jewelry.

The shelter in Batu Cave describes activities related to daily activities, such as food gathering, food processing, tool making, and living. So far, no human skeleton has been found to indicate burial activity. Several human teeth from Batu Cave were found scattered without human skeletal context. An explanation of the human supporting culture still must be done with further research. Based on the thickness of Batu Cave sediments, the potential for finding human remains is quite large. Further research is needed to find human remains and confirm the role of Batu Cave in the settlement of the Meratus karst area in the past.

Previous discoveries of human skeletons have been reported at several cave sites in the Mantewe karst. Human skeletal fragments were first found in excavations at the Liang Ulin 2 site (Oktrivia et al, 2013). The findings were in the form of teeth and skull bones which were very fragmentary in condition. The results of the analysis show that the remaining skeletons from Liang Ulin 2 are known to come from six individuals, consisting of 3 adults and 3 children (Sugiyanto et al., 2015). Individual identification successfully reveals information about population affiliation and special character. The rest of the Liang Ulin 2 skeleton is known as the Mongoloid race, experiencing malnutrition, recognizing the pangur culture, and chewing betel nut (Sugiyanto et al., 2016). The findings of human remains were also found in Liang Bangkai 10. The results of the analysis of the skeletal remains at Liang Bangkai 10 found at least four human individuals consisting of 2 adults who were buried almost intact, 1 adult individual, and 1 child whose grave is unknown (Sugiyanto et al, 2015). Human support for culture in Liang Bangkai 10 is known to come from the Mongoloid race with cultural characteristics of pangur and chewing betel (Sugiyanto et al, 2016).

\section{CONCLUSION}

The archaeological findings found in Batu Cave are evidence of human dwelling in the location. The occupancy in Batu Cave is shown by activities related to meeting the needs of daily life. The characteristics of the occupancy in Batu Cave 
show the same characteristics as other dwelling caves in the southeastern Meratus Mountains. This can be seen in the choice of materials for making tools, which use stone and bone. Stone as a tool material is more widely used than bone. The thing that distinguishes Batu Cave from other sites is the use of shells as a material for making tools. So far, shell artifacts have not been found at another residential site in southeast Meratus.

The results of the dating analysis in Batu Cave have not shown reliable figures. As a comparison, the data were obtained from Liang Bangkai 1. Chronology dating at layer 1 in Liang Bangkai 1 yields the calendar 5920-6045 calBP. This period is equivalent to the results of Batu Cave dating of layer A at TP 1 with a chronology ranging from 6065-5650 calBP. The chronology of the occupancy in Batu Cave is likely to have the same timeframe as Liang Bangkai 1. This assumption is supported by several characteristics of the same findings. More analysis of the dating needs to be done to get a reliable chronology. In this research, no evidence has been found to explain who the inhabitants of Batu Cave are. Excavation has not reached a sterile layer. 


\section{DAFTAR PUSTAKA}

Andrefsky, W. (1998). Lithics Macroscopic Approaches to Analysis. Cambridge: Cambridge University Press.

Clarkson, C., \& Sue, O. (2006). An Introduction to Stone Artifact Analysis. In J. Balme \& A. Paterson (Eds.), Archaeology in Practice A Student Guide to Archaeological Analysis (pp. 159-206). Carlton: Blackwell Publishing.

Fajari, N. M. E. F. (2010). Gerabah Gua Payung: Jejak-jejak Austronesia di Kalimantan Bagian Selatan. Naditira Widya, 4(1), pp. 11-24.

Fajari, N. M. E., \& Kusmartono, V. P. R. (2013). The excavation of Gua Payung, South Kalimantan, Indonesia. Bulletin of the Indo-Pacific Prehistory Association, 33(Figure 1), pp. 20-23.

Fajari, N. M. E., \& Oktrivia, U. (2015). Liang Ulin 2: Informasi Baru Prasejarah Kalimantan Selatan. Naditira Widya, 9(2), pp. 93-106.

Fajari, N. M. E., Wasita, Herwanto, E., Sugiyanto, B., Kuswanta, G. D., Suryono, T., \& Wibisono, M. W. (2018). Eksplorasi Arkeologi Kawasan Karst Pegunungan Meratus di Kabupaten Kotabaru, Kalimantan Selatan. Banjarbaru.

Noviyanti, R. (2014). Pengaruh Konsumsi Minuman Tuak Terhadap Erosi Gigi di Kecamatan Maiwa Kabupaten Enrekang. Universitas Gadjah Mada.

Nurani, A., \& Hascaryo, A. T. (2010). Pola Hidup Komunitas Gua Hunian Prasejarah Kawasan Karst Blora. Berkala Arkeologi, 30(1), pp. 23-38. https://doi.org/10.30883/jba.v30i1.385

Oktrivia, U., Hindarto, I., \& Herwanto, E. (2013). Potensi Arkeologi di Sekitar Bukit Ulin Kecamatan Mantewe Kabupaten Tanah Bumbu. Banjarbaru.

Petchey, F., Ulm, S., David, B., McNiven, I. J., Asmussen, B., Tomkins, H., ... Mandui, H. (2013). High-resolution radiocarbon dating of marine materials in archaeological contexts: Radiocarbon marine reservoir variability between Anadara, Gafrarium, Batissa, Polymesoda spp. and Echinoidea at Caution Bay, Southern Coastal Papua New Guinea. Archaeological and Anthropological Sciences, 5(1), pp. 69-80. https:// doi.org/10.1007/s12520-012-0108-1

Poesponegoro, M. D., \& Notosusanto, N. (2010). Sejarah Nasional Indonesia I Zaman Prasejarah di Indonesia (R. P. Soejono \& R. Z. Leirissa, Eds.). Jakarta: Balai Pustaka.

Prasetyo, B. (2004). Juga Industri Tulang. In T. Simanjuntak, R. Handini, \& B. Prasetyo (Eds.), Prasejarah Gunung Sewu (pp. 177-185). Jakarta: Ikatan Ahli Arkeologi Indonesia.

Ramsey, C. B. (2017). Methods for Summarizing Radiocarbon Datasets. Radiocarbon, 59(6), pp. 1809-1833. https://doi.org/10.1017/RDC.2017.108

Reimer, P. J., Bard, E., Bayliss, A., Beck, J. W., Blackwell, P. G., Ramsey, C., ... Plicht, J. (2013). Intcal13 and Marine13 Radiocarbon Age Calibration Curves 0-50,000 Years Cal BP. Radiocarbon, 55(4), pp. 1869-1887. 
https://doi.org/10.2458/azu_js_rc.55.16947

Reitz, E. J., \& Wing, E. S. (2008). Zooarcaheology (Edisi Kedua). Cambridge: Cambridge University Press.

Sharer, R., \& Ashmore, W. (2003). Archaeology Discovering Our Past. New York: McGraw-Hill.

Sugiyanto, B. (2015). Potensi Arkeologi Prasejarah Kabupaten Tanah Bumbu dan Ancaman yang Dihadapinya. Naditira Widya, 9(1), pp. 1-14.

Sugiyanto, B., Cahyaningtyas, Y. N., Sulistyo, R. B., \& Sundoko. (2015). Penelitian Prasejarah Gua Sugung, Desa Mantewe, Kecamatan Mantewe, Kabupaten Tanah Bumbu, Kalimantan Selatan. Banjarbaru.

Sugiyanto, B., \& Jatmiko. (2014). Ekskavasi dan Eksplorasi Situs-situs Hunian Prasejarah di Kawasan Karst Mantewe, Kabupaten Tanah Bumbu, Kalimantan Selatan. Berita Penelitian Arkeologi, 7(1), pp. 1-56.

Sugiyanto, B., Jatmiko, Susanto, N. N., Cahyaningtyas, Y. N., Hindarto, I., Herwanto, E., \& Sundoko. (2014). Penelitian Gua-gua Hunian Prasejarah di Bukit Bangkai, Kabupaten Tanah Bumbu, Provinsi Kalimantan Selatan. Banjarbaru.

Sugiyanto, B., Noerwidhi, S., Oktrivia, U., \& Sundoko. (2016). Penelitian Identifikasi Kubur pada Situs Liang Bangkai dan Liang Ulin, Kecamatan Mantewe, Kabupaten Tanah Bumbu, Kalimantan Selatan. Banjarbaru.

Suroto, H. (2009). Fungsi Kulit Kerang Cypraea Moneta dalam Perdagangan di Pegunungan Tinggi Papua. Kapata, 5(9), pp. 96-102.

Szabo, K., Brumm, A., \& Belwood, P. (2007). Shell Artifact Production at 32 , 000 28,000 BP in Island Southeast Asia by Katherine Szabo The favouring of one of these hypotheses over the other. Current Anthropology, 48(5), pp. 701-724. https://doi.org/10.1086/520131

Tim Penulis. (1999). Metode Penelitian Arkeologi (N. Harkantiningsih, B. Prasetyo, Y. Eriawati, A. Novita, N. Laili, \& T. Simanjuntak, Eds.). Jakarta: Pusat Penelitian Arkeologi Nasional.

Widianto, H., \& Handini, R. (2003). Karakteristik Budaya Prasejarah di Kawasan Gunung Batubuli, Kalimantan Selatan: Mekanisme Hunian Gua PascaPlestosen. Berita Penelitian Arkeologi, 12, pp. 1-91.

Wiradnyana, K. (2017). Identifikasi Budaya Prasejarah Dari Artefak Di Situs Bukit Kerang Kawal Darat I. Sangkhakala, 20(2), pp. 79-87. https://doi.org/10.24832/bas.v20i2.282 